\title{
An investigation on relationship between CRM and organizational learning through knowledge management: A case study of Tehran travel agency
}

\author{
Mirza Hasan Hosseini ${ }^{a^{*}}$, Babak Nemati ${ }^{\mathrm{b}}$ and Nazli Sadeghi ${ }^{\mathrm{b}}$
}

\begin{abstract}
${ }^{a}$ Assistant Professor, Head of Business Administration Department University of Payame Noor ${ }^{b}$ Department of Accounting and Management, Payam Noor university, Damavand, Iran

\section{H R O N I C L E \\ A B S T R A C T}

Article history:

Received October 16, 2012

Received in revised format

27 December 2012

Accepted 12 January 2013

Available online

January 142013

Keywords:

Customer relationship

management (CRM)

Organizational learning

Knowledge management

Customer relationship management (CRM) plays essential role on the success of many business units. CRM integrates necessary data from internal and external sources to assist managers and employees for business development. This paper attempts to analyze relationship between CRM, organizational learning, and knowledge management. Research population includes travel agencies in Tehran, Iran and their manager are considered for the purpose of this study. This research has four variables 1- Successful implementation of KM, 2- Organizational learning, 3- customer orientation, and 4- information share with customers. The preliminary results of this survey indicate that any development of CRM will significantly contribute relative efficiency of this travel agency. The results also indicate that there is a meaningful relationship among components of CRM including organizational learning, and knowledge management in this travel agency.
\end{abstract}

\section{Introduction}

Organizational knowledge management (KM), often called as "the learning organization," plays an essential role in the context of organizational literature and there are literally many studies associated with. Alavi and Leidner (2001) described KM as a tool for management of knowledge based tangible resources depending on how they are combined and applied, which is also a function of the firm's capabilities. Sun et al. (2006) described this process as "adaptive learning," the process of using the firm's necessary information to extract market and competitive intelligence. CRM is the primary key to this process of continuous adaptation of firms to environments based on monitoring external changes and adapting internal cultures and processes in response to external challenges (Senge et al., 1999).

*Corresponding author. Tel.: +989125984376, Fax: +9888764636

E-mail addresses: nematibabak@yahoo.com (M. H. Hosseini) 
During the past few years, there have been tremendous increase in adaptation of CRM systems within organizations (DeSisto, 2005). CRM implementation has normally taken the form of extended sales automation systems and enterprise resource planning (ERP) systems, in most cases replicating an existing process based on modern database and networking systems. In a survey conducted in 2004, $60 \%$ of midsized firms indicated their objective to initiate or expand their CRM implementation, while only $2 \%$ specified they currently had no plans to use a CRM system (Neuborne, 2005). Over the past decade, there are increasing CRM developers for small business units (Myron, 2005). The resulting solutions have effectively improved traditional sales management, providing with real-time sales planning, pipeline reporting, sales team development and project tracking capabilities. The firm's CRM system need to disclose important factors for clients promoting a consumer-oriented philosophy, using customer-based measures, developing end-to-end customer management processes for serving customers, providing customer support, and tracking various sale's perpectives. In other words, the system needs to create a holistic view of customers' sales and services information.

\section{Literature review}

\section{1. $C R M$}

A significant portion of CRM research is associated with key and strategic account management (Arantola, 2006; Björn \& Pardo 2006; Lane \& Piercy 2004), CRM methodologies and practices (Chalmeta 2006; Madill et al. 2005), customer value drivers and value creation (Golfetto \& Gibbert 2006; Richards \& Jones 2006) and customer segmentation practices (Jonker et al. 2004; Kim et al. 2006). The concept of CRM has also been discussed quite broadly (Choy et al. 2004; InJazz \& Popovich, 2003; Richards \& Jones 2006).

CRM can be explained as a process involving people and technology where the primary objective is to maximize the customer information and use it to increase customer loyalty and to retain customers' business as much as possible. It is an integrated method to focuse on customer retention and relationship development (Choy et al. 2002; InJazz \& Popovich 2003). According to Chalmeta (2006), CRM is a customer-focused business strategy, which integrates sales, marketing and customer care service, dynamically. The aim of CRM strategy is to create and add value both within company and its customers. Richards and Jones (2006, p. 3) defined CRM as a set of business activities supported by both technology and processes directed by strategy to improve business performance in the area of customer management. CRM became important as a competitive industry in late 1990s and customer satisfaction, producing high-quality products and providing high-quality customer service presently play important part of corporate's objective (Choy et al. 2004). Besides, CRM can be already understood as core competence of firms (Kim et al. 2006). Therefore, we can conclude that customer orientation and CRM have become under consideration in many organizations. CRM supports the process of learning by helping the sales organization, management, customers, resellers and suppliers to better understand the effect of new implementation and implementing patterns of products and services supplied by the firm. An effective CRM must help development of a knowledge orientation in each of the firm's stakeholders. Organizational knowledge orientation means that (1) only best available practices are copied, (2) everyone works from the same active best practice template, (3) best practices are copied as closely as possible, (4) adopted practices are tested and adapted only after good results are accomplished, and (5) best practice templates are maintained after adoption by the organization occure, successfully (Szulanski \& Winter, 2000).

\subsection{Organizational learning}

As Dawes and coworkers (2005) indicated, organizational learning has a complex framework and elusive concept due to different reasons, and that is why a widely accepted definition has not still appeared. According to Garvin (1993), the discussions concerning learning organizations have been 
filled with mystical and philosophical. Garvin (1993) defined learning organization as "an organization skilled at creating, acquiring, and transferring knowledge, and at modifying its behavior to reflect new knowledge and insights". Dawes (2005) recommended that organizational learning is a process including information acquisition, information dissemination and shared interpretation. According to Jiménez- Jiménez and Cegarra- Navarro (2006), organizational learning incorporates four perspectives, which are information acquisition, distribution, interpretation and memory. Organizational learning can be also seen as the capability of a business unit to learn from itself, its mistakes, its inefficiency and its employees and to harness and implement the knowledge for competitive advantage (Appelbaum \& Callagher, 2000).

Huber (1996) stated that organizational memory, or knowledge retention played important role on organizational learning. According to Huber (1996) and Weick (1979b), before learning happens, the knowledge ought to be retained and retrievable. Huber (1996) also explained that learning was impacted by attention, which in turn is concentrated by knowledge already retained. Information distribution is influenced by decisions made based on criteria and facts kept in knowledge retention structures. In addition, interpretation of new knowledge is influenced by the cognitive maps or schemas generated through past experience.

\subsection{Knowledge management}

Recently, many firms have integrated their CRM and KM efforts because they realize KM plays a primary key for the success of CRM implementation (Dous et al., 2005). Detecting the high value customer is a sophisticated knowledge task and it determines the range of profiles among current customers. Technology helps but KM puts the data processing power of technology to effective implementation. Collaborating with customers normally needs a strong grasp of tacit knowledge exchange, and forecasting new customer requirements, which could be delivered based on statistical techniques with technologies. However, it can only be performed successfully when the dimension of tacit knowledge exchange and collaboration can also be deployed (Lambe, 2008). Therefore, CRM processes depend on signidificant amounts of knowledge (Bueren et al., 2005). CRM is associated with managing customers knowledge to understand their needs and to serve them, properly (Beijerse, 1999). CRM is definitely associated with KM disciplines, thus, the existence of sufficient and continually updated customer knowledge is essential for an effective CRM system (Stefanou et al., 2003). Given the relative importance of KM systems in the current customer-centric business environment, we need to have a simple and overall framework to integrate the traditional CRM functionalities for the management and application of the customer-related knowledge (Beijerse, 1999). According to Zablah et al. (2004), we need KM as the main sub process of CRM because, to manage CRM effeciently, firms need to develop their capabilities based on customer KM processes. Since these capacities are not easy to imitate, they can become a source of competitive advantage (Shi \& Yip, 2007). From a resource-based perspective (Penrose, 1959; Wernerfelt, 1984), customer knowledge become a valuable and rare asset for businesses, which could create a rapid response to customers' needs for adapting to changing markets (Shi \& Yip, 2007). Whereas the search for competitive advantage is the key factor of current strategic management, we need to focues more on collecting information on customers in the context of a relationship, and offer customers.

\subsection{Hypothesis}

$\mathrm{H}_{1}$ : Successful implementation of KM has a positive and significant relationship with CRM.

$\mathrm{H}_{2}$ : Organizational learning has a positive and significant relationship with successful implementation of CRM.

$\mathrm{H}_{3}$ : Customer orientation has a positive and significant relationship with successful implementation CRM. 
$\mathrm{H}_{4}$ : Sharing information with customers has a positive and significant relationship with organizational learning.

\section{Methodology}

\subsection{Validity and reliability}

Measurement tool of this research is a questionnaire with 22 questions and it is divided into 4 sections namely, knowledge management, organizational learning, CRM, and information shared among customers. To ensure content validity, a pretest of the questionnaire was made by eight experts (five masters in management and three business consultants). Authors used a reliability coefficient, the Cronbach alpha, to analyze the reliability of the scale. This coefficient evaluates the consistency of the entire scale, and is the most commonly used measure. The Cronbach alpha is close to 0.75 for all the variables, which confirms the scale reliability.

\subsection{Population and sampling}

Research population is all travel agency in Tehran city that statistics is shown 2500. Regard to following formulas for limited population and error 0.07 , sample is obtained using the following formula,

$$
n=\frac{N \times z_{\alpha / 2}^{2} \times p \times q}{\varepsilon^{2} \times(N-1)+z_{\alpha / 2}^{2} \times p \times q},
$$

where $N$ is the population size, $p=1-q$ represents the yes/no categories, $z_{\alpha / 2}$ is CDF of normal distribution and finally $\varepsilon$ is the error term. Since we have $p=0.5, z_{\alpha / 2}=1.96$ and $N=2500$, the number of sample size is calculated as $n=181$. After assigning scores to the questionnaires and calculating the descriptive indices for the purpose of testing the hypotheses and generalizing the results to the population, t-tests, Pearson Correlation coefficients, and regression analysis were used. In order to assess the significance of the variables under investigation, an introductory test was used. This test examined $\mathrm{H}_{0}$ and $\mathrm{H}_{1}$ as follows,

$$
\begin{cases}H_{0}: & \mu \leq 3 \\ H_{1}: & \mu>3\end{cases}
$$

The summary of results obtained from the tests, have been presented in Table 4 . As can be seen, all variables are significant at the error level of 5 percent $(\mathrm{p}<0.05)$ and the given degree of freedom, and they are within the limits. The differences in degrees of freedom are due to the fact that some of the subjects have not provided answers to some of the items. In our survey, $74.5 \%$ of the participants were male and $25.5 \%$ of them were female. Fig. 1 shows details of participants in terms of their age and educationl backgrounds.

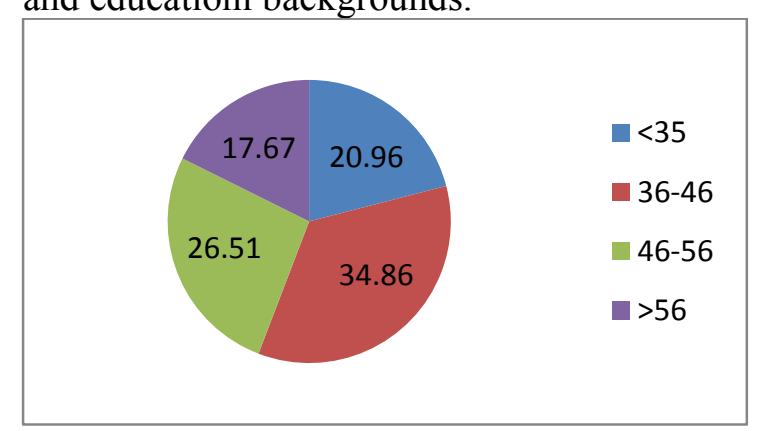

Fig. 1. (a). Age diversity

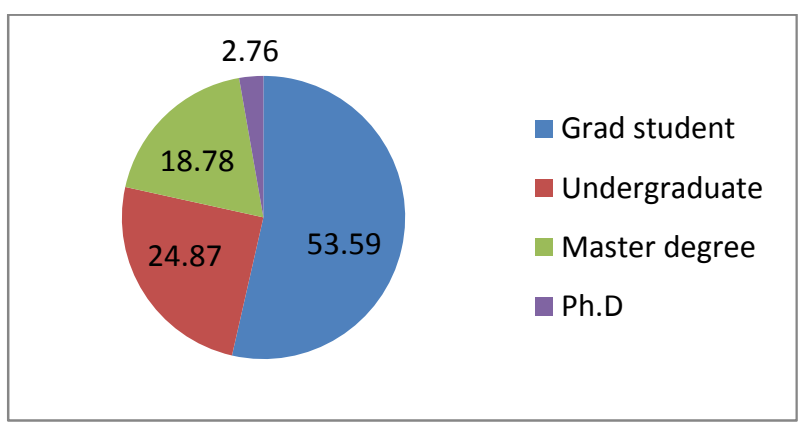

Fig. 1. (b). Years of education

Fig. 1. Personal characteriscs of participants 


\section{Results}

Table 1 shows details of our findings associated with mean of different questions of our survey.

\section{Table 1}

Mean distribution of opinions of respondents to questions of research

\begin{tabular}{|c|c|c|c|}
\hline No. & Variable & Question & Mean \\
\hline 1 & \multirow[t]{6}{*}{$\begin{array}{l}\text { Knowledge } \\
\text { management }\end{array}$} & $\begin{array}{l}\text { Firm has established processes to acquire knowledge about key } \\
\text { customers }\end{array}$ & 2.52 \\
\hline 2 & & $\begin{array}{l}\text { Firm fully understands needs of its key customers thanks to its } \\
\text { knowledge orientation }\end{array}$ & 2.54 \\
\hline 3 & & $\begin{array}{l}\text { Firm provides channels to enable ongoing two-way communication } \\
\text { with key customers }\end{array}$ & 3.13 \\
\hline 4 & & $\begin{array}{l}\text { Firm's organizational culture stimulates acquisition of knowledge and } \\
\text { transmission between employees }\end{array}$ & 3.54 \\
\hline 5 & & Firm encourages employees to share knowledge & 3.28 \\
\hline 6 & & $\begin{array}{l}\text { Firm has designed processes to facilitate knowledge transmission } \\
\text { between the different functional areas }\end{array}$ & 3.99 \\
\hline 7 & \multirow[t]{5}{*}{$\begin{array}{l}\text { Organizational } \\
\text { learning }\end{array}$} & $\begin{array}{l}\text { Training programs are designed to help employees develop skills } \\
\text { needed to manage customer relationships appropriately }\end{array}$ & 2.80 \\
\hline 8 & & Top management considers CRM a top priority & 3.66 \\
\hline 9 & & $\begin{array}{l}\text { Top management is strongly involved in implementation of CRM } \\
\text { strategy }\end{array}$ & 3.69 \\
\hline 10 & & $\begin{array}{l}\text { Organizational structure is designed following customer-centric } \\
\text { approach }\end{array}$ & 3.60 \\
\hline 11 & & The different departments work together to achieve CRM objectives & 4.06 \\
\hline 12 & \multirow[t]{6}{*}{ CRM } & Firm's business objectives are oriented to customer satisfaction & 3.76 \\
\hline 13 & & $\begin{array}{l}\text { Firm closely monitors and assesses its level of commitment in serving } \\
\text { customer needs }\end{array}$ & 2.50 \\
\hline 14 & & $\begin{array}{l}\text { Firm's competitive advantage is based on understanding customer } \\
\text { needs }\end{array}$ & 2.53 \\
\hline 15 & & $\begin{array}{l}\text { Firm's business strategies are driven by objective of increasing value } \\
\text { for customers }\end{array}$ & 1.93 \\
\hline 16 & & $\begin{array}{l}\text { Individualized information about each customer is available at all } \\
\text { contact points }\end{array}$ & 2.49 \\
\hline 17 & & Firm frequently measures customer satisfaction & 1.94 \\
\hline 18 & \multirow{5}{*}{$\begin{array}{l}\text { Information } \\
\text { share between } \\
\text { customers }\end{array}$} & Sharing information with customers is considered important. & 1.90 \\
\hline 19 & & $\begin{array}{l}\text { Your firm's customers are willing to share sensitive operational } \\
\text { information with the firm. }\end{array}$ & 3.15 \\
\hline 20 & & Your firm's customers regularly keep in contact with one another. & 2.68 \\
\hline 21 & & $\begin{array}{l}\text { Your firm's customers advise each other concerning the use of your } \\
\text { firm's products. }\end{array}$ & 3.62 \\
\hline 22 & & $\begin{array}{l}\text { Your firm's customers are an important source of planning information } \\
\text { for your firm. }\end{array}$ & 2.10 \\
\hline
\end{tabular}

After conducting a t-test, the relationships between variables were examined by calculating the correlation coefficients among them that shown in table 3 . 
Table 3

Statistical measures of t-test for examining the significance of variables under study

\begin{tabular}{|c|c|c|c|c|c|c|}
\hline Variables & t-observed & (df) & $\begin{array}{l}\text { Obtained Error } \\
\text { (two tailed) }\end{array}$ & $\begin{array}{c}\text { Significant } \\
\text { difference }\end{array}$ & \multicolumn{2}{|c|}{ Confidence Interval } \\
\hline Successful implementation of KM & 29.180 & 165 & 0.000 & 1.1667 & 1.0875 & 1.2458 \\
\hline Organizational learning & 25.036 & 164 & 0.000 & 1.0550 & 0.9716 & 1.1384 \\
\hline customer orientation & 26.820 & 162 & 0.000 & 1.1907 & 1.1028 & 1.2786 \\
\hline information share with customers & 27.608 & 164 & 0.000 & 1.808 & 1.0961 & 1.2655 \\
\hline
\end{tabular}

A summary of the research findings obtained from Pearson Correlation Coefficient test along with Means and Standard Deviations of the variables have been illustrated individually in Table 4.

Table 4

The results of Pearson correlation coefficients, means, and standard deviations

\begin{tabular}{|c|c|c|c|c|c|}
\hline Hypothesis & Variables & Mean & Standard Deviation & $\begin{array}{l}\text { Pearson Correlation } \\
\text { Coefficient }\end{array}$ & P-value \\
\hline H1 & $\begin{array}{l}\text { Successful implementation of KM } \\
\text { CRM }\end{array}$ & $\begin{array}{l}4.14 \\
4.13\end{array}$ & $\begin{array}{l}0.33 \\
0.33\end{array}$ & 0.517 & 0.000 \\
\hline $\mathrm{H} 2$ & $\begin{array}{l}\text { Organizational learning } \\
\text { Successful implementation of CRM }\end{array}$ & $\begin{array}{l}4.05 \\
4.13\end{array}$ & $\begin{array}{l}0.46 \\
0.48\end{array}$ & 0.36 & 0.000 \\
\hline H3 & $\begin{array}{l}\text { customer orientation } \\
\text { Successful implementation of CRM }\end{array}$ & $\begin{array}{l}4.18 \\
4.13\end{array}$ & $\begin{array}{l}0.46 \\
0.48\end{array}$ & 0.25 & 0.007 \\
\hline H4 & $\begin{array}{l}\text { information share with customers } \\
\text { Organizational learning }\end{array}$ & $\begin{array}{l}4.05 \\
4.18\end{array}$ & $\begin{array}{l}0.46 \\
0.46\end{array}$ & 0.198 & 0.032 \\
\hline
\end{tabular}

The results of Table 4 indicate that there is a meaningful relationship among components of CRM including organizational learning, and knowledge management in this travel agency.

\section{Conclusion and discussion}

In this paper, we have explained the relative importance of CRM to improve a firm's innovation capability and to enhance a firm's competitive advantage. The aim of this research has been to provide a relationship between CRM, organizational learning, and knowledge management. In this research 200 questioners have distributed that which 181 of them were filled. Also 4 variables of Successful implementation of KM, Organizational learning, customer orientation, and information share with customers, have been investigated. Statistical test for the hypotheses of this survey are $4.14,4.05,4.18,4.05$ and we have concluded that all research hypotheses could be accepted.

Based on the results of the present analysis, the relationships between the CRM, organizational learning, and knowledge management in travel agency have been confirmed. In other words, by establishing these systems, travel agency will witness an increase in efficiency, staff satisfaction, and eventually customer satisfaction.

Apparently, to attain the desired learning capability, firms must look beyond internal efforts and include collaborative activities with their customers. As customer relationship management continues to evolve with the aid of more advanced IT, the potential influence of customer involvement on innovation capability could increase.

In today's business, customer-oriented approach is one of the best strategies to gain market share. Therefore, travel agencies must consider customer's requirements and expectations to improve level of satisfaction in delivered services. In other words, designers and planners in CRM system must explore todays' tendency and view of potential customers for more consistency between CRM system and customer's demands. 
Successful implementation of KM in organization can facilitate to reach information about customers. Therefore, it can enhance to manage entered information to system. and surly, all of this increase organization's efficiency to handle customer's expectations.

CRM and organizational learning and knowledge management are within potential context for further researches and experts can perform various surveys to improve level of this issue. Authors suggest areas that can study in future. For example, organizational profit, employee satisfaction, productivity, effectiveness and so on can be a list of variations that analyze their relationships with variables in this research.

\section{References}

Alavi, M., \& Leidner, D. E. (2001). Review: Knowledge management and knowledge management systems: Conceptual foundations and research issues. MIS Quarterly, 25, 107-136.

Appelbaum, S. H., Gallagher J. 2000. The competitive advantage of organizational learning. Journal of Workplace Learning: Employee Counselling Today, 12 (2), 40-56.

Arantola, H. (2006). Customer insight: Uusi väline liiketoiminnan kehittämiseen. WSOYpro. 158 p. (in Finnish)

Beijerse, R. P. (1999). Questions in KM: Defining and conceptualising a phenomenon. Journal of Knowledge Management, 3(2), 94-109.

Björn, S.I., Pardo, C. (2006). Are key account relationships different? Empirical results on supplier strategies and customer reactions. Industrial Marketing Management. 13p.

Bueren, A., Schierholz, R., Kolbe, L. M., \& Brenner, W. (2005). Improving performance of customer-processes with KM. Business Process Management Journal, 11(5), 573-588.

Chalmeta, R. (2006). Methodology for customer relationship management. The Journal of Systems and Software, 79, 1015-1024.

Choy, K. L., Lee, W. B., \& Lo, V. (2002). Development of a case based intelligent customer-supplier relationship management system. Expert systems with Applications, 1-17.

Choy, K. L., Lee, W. B., \& Lo, V. (2004). An enterprise collaborative management system - a case study of supplier relationship management. The Journal of Enterprise Information Management, 17 (3), 191-207.

Dawes, P. L., Lee, D.Y., \& Midgley, M. (2005). Organizational learning in high-technology purchase situations: The antecedents and consequences of the participation of external IT consultants. Industrial Marketing Management, 36(3), 285-299.

Day, G. S. (2000). Managing market relationships. Journal of the Academy of Marketing Science, 28, 24-30.

DeSisto, R. (2005). CRM on demand: The myth and promise of no software. Gartner Group Publications.

Dous, M., Kolbe, L., Salomann, H., \& Brenner, W. (2005). KM capabilities in CRM: Making knowledge for, from and about customers work. Proceedings of the eleventh Americas conference on information systems Omaha, NE, USA, 167-178.

Golfetto, F., \& Gibbert, M. (2006). Marketing competencies and the sources of customer value in business markets. Industrial Marketing Management, 35, 904-912.

Huber, G. P. (1996). Organizational Learning: The Contributing Processes and the Literature. In M. D. Cohen \& L. S. Sproull (Eds.), Organizational Learning (pp. 124-162). Thousand Oaks, CA: Sage.

InJazz, J. C., \& Popovich, K. (2003). Understanding customer relationship management (CRM): People, process and technology. Business Process Management Journal, 9(5), 672-688.

Jiménez-Jimenéz, D., \& Cegarra-Navarro, J. G. (2007). The performance effect of organizational learning and market orientation. Industrial Marketing Management. 36, 694-708 
Jonker, J-J., Piersma, N., \& Van den Poel, D. (2004). Joint optimization of customer segmentation and marketing policy to maximize long-term profitability. Expert Systems with Applications, 27, 159-168.

Kim, S-Y, Jung, T-C, Suh, E-H, \& Hwang, H-S. 2006. Customer segmentation and strategy development based on customer lifetime value: A case study. Expert Systems with Applications. 31, 101-107.

Lambe, P. (2008). Knowledge-based CRM: A map. Retrieved from: http://www.greenchameleon.com/thoughtpieces/kcrm.pdf.

Lane, N., \& Piercy, N. (2004). Strategic customer management: Designing a profitable future for your sales organization. European Management Journal, 22 (6), 659-668.

Madill, J.J., Haines, Jr. G.H. \& Riding, A.L. (2007). Managing customer relationships: Account manager turnover and effective account management. Industrial Marketing Management, 36(2), 241-248.

Myron, D. (2005). Back to double-digit growth. CRM Magazine, 9, 31.

Neuborne, E. (2005). A second act for CRM. Inc., 27, 40-42.

Penrose, E. T. (1959). The theory of the growth of the firm. New York: Villey.

Richards, K., \& Jones, E. (2006). Customer relationship management: Finding value drivers. Industrial Marketing Management, 37, 120-130.

Senge, P., Kleiner, A., Roberts, C., Ross, R., Roth, G., \& Smith, B. (1999). The dance of change: The challenges of sustaining momentum in learning organizations. New York: Doubleday/Currency.

Shi, J., \& Yip, L. (2007). Driving innovation and improving employee capability: The effect of customer knowledge sharing on CRM. The Business Review, 7(1), 107-112.

Stefanou, C. J., Sarmaniotis, C., \& Stafyla, A. (2003). CRM and customer-centric KM: An empirical research. Business Process Management Journal, 9(5), 617- 634.

Sun, B., Li, S., \& Zhou, C. (2006). “Adaptive” learning and "proactive' customer relationship management. Journal of Interactive Marketing, 20, 82-96.

Szulanski, G., \& Winter, S. (2000). Getting it right the second time. Harvard Business Review, 80, 62-69.

Weick, K. E. (1979b). The Social Psychology of Organizing. Reading, MA: Addison Wesley.

Zablah, A. R., Bellenger, D. N., \& Johnston, W. J. (2004). An evaluation of divergent perspectives on customer relationship management: Towards a common understanding of an emerging phenomenon. Industrial Marketing Management, 33, 475-489. 